\title{
Ventilator Bundles in Transition: From Prevention of Ventilator- Associated Pneumonia to Prevention of Ventilator-Associated Events
}

\author{
Richard H Kallet
}

\begin{abstract}
Implementation of ventilator bundles is associated with reductions in ventilator-associated pneumonia (VAP). However, the new surveillance model of ventilator-associated events (VAEs) has shifted the focus from VAP to objective, generalized signs of pulmonary decompensation not specific to VAP. This raises the question of whether the ventilator bundle also is effective in reducing VAE. This narrative review examined 6 studies published since 2013 that assessed the impact of ventilator bundles on the incidence of VAE, and a seventh study that examined its impact on mortality. All 7 studies were low-level evidence, and only 1 study was prospective. The findings among the studies were inconsistent, and the only prospective study found no difference in bundle adherence between those who did and did not develop VAE. However numerous factors may explain the apparent lack of efficacy. Most of these factors were related to the retrospective nature of the studies, such as suboptimal documentation of bundle procedures and the presence of potential non-modifiable risk factors, as well as insufficient performance of most bundle components. In some studies, low VAE incidence also raised uncertainty about the veracity of results. Despite these limitations, there was evidence suggesting that stress ulcer prophylaxis may increase VAE risk, and oral care with chlorhexidine may increase both VAE and mortality risk. The largest study found significant reductions in duration of intubation with weaning, sedation, and head of bed elevation, as well as reduced mortality risk with weaning and sedation bundle elements. Nonetheless, these studies should be useful in designing future prospective controlled studies to determine what elements of a future prevention bundle might be effective in reducing VAEs. At this juncture, and based on the limited evidence to date, it appears that incorporating daily sedation interruptions and spontaneous breathing trials are the factors most likely to reduce VAEs. Key words: ventilatorassociated pneumonia; ventilator-associated events; ventilator-associated conditions; infection-related ventilator-associated complications; ventilator bundle. [Respir Care 2019;64(8):994-1006. (C) 2019 Daedalus Enterprises]
\end{abstract}

\section{Introduction}

Reducing hospital-acquired infections is at the forefront of efforts to improve patient-centered outcomes and to reduce health care expenditures by monitoring hospitals for preventable complications. An early initiative involved standardizing evidence-based practices that reduce ventilator-associated pneumonia (VAP) into a package generically referred to as a "ventilator bundle."1 These endeav-

Mr Kallet is an Associate Editor for RespiRATORY CARE.

Mr Kallet discloses a relationship with the Asthma and Allergy Prevention Company. ors consequently brought to the forefront some inherent limitations in the diagnosis of VAP.

In 2011, the Department of Health and Human Services enlisted help from the Centers for Disease Control and Prevention, the Critical Care Society Collaborative

\footnotetext{
Mr Kallet presented a version of this paper at the New Horizons Symposium: Ventilator-Associated Events-Surveillance and Understanding at the AARC Congress 2018, held December 4-7, 2018, in Las Vegas, Nevada.

Correspondence: Richard H Kallet MSc RRT FAARC. E-mail: richkallet@gmail.com.
}

DOI: $10.4187 /$ respcare. 06966 
Table 1. Elements of a Ventilator Bundle Used to Reduce Incidence of VAP

\begin{tabular}{|c|c|}
\hline Element & Rationale for Preventing VAP \\
\hline Head of bed elevation: $30-45^{\circ}$ & $\begin{array}{l}\text { Reduce the potential for gastric reflux and aspiration of contaminated } \\
\text { orogastric secretions }\end{array}$ \\
\hline \multirow[t]{2}{*}{ Avoidance of nasogastric tubes, limiting the use of orogastric tubes } & $\begin{array}{l}\text { Reduce upper airway contamination by preventing sinus infections } \\
\text { and/or improve lower esophageal sphincter competency through } \\
\text { the absence of foreign objects and ease of gastric fluid/bacterial } \\
\text { migration via an open pathway up the esophagus }\end{array}$ \\
\hline & PVC materials used in catheters facilitates bacterial growth \\
\hline Oral care with chlorhexidine & $\begin{array}{l}\text { Reduce the introduction and load of potentially pathogenic microbes } \\
\text { into the oropharynx and, by extension, colonization of the lower } \\
\text { respiratory tract }\end{array}$ \\
\hline Protective cover for oral ("tonsil-tip") suction devices when not in use & $\begin{array}{l}\text { Protective covers reduce the risk of introducing potentially } \\
\text { pathogenic bacteria into the oropharynx }\end{array}$ \\
\hline Spontaneous breathing trial & Reduce exposure to mechanical ventilation \\
\hline Daily sedation interruption & Reduce exposure to mechanical ventilation \\
\hline Deep vein thrombosis prophylaxis & Extraneous to VAP prevention \\
\hline Stress ulcer prophylaxis & Extraneous to VAP per se* \\
\hline Specially designed ETT and associated devices & Reduction of secretions pooled above the ETT cuff \\
\hline ETT with subglottic drainage & $\begin{array}{l}\text { Reduction of secretion seepage around or through microchannels in } \\
\text { the ETT }\end{array}$ \\
\hline Silver-coated ETT, ETT with tapered cuff design, or ETT made with & Reduction of microbes in biofilm residing in the ETT lumen \\
\hline
\end{tabular}
polyurethane material (vs PVC material)

Special catheter to remove biofilm from the ETT lumen

Automated monitoring and control of ETT cuff pressure to prevent gross aspiration and limit the degree of miroaspiration of orogastric secretions

Ventilator circuit-related

Circuit replacement weekly or when visibly soiled

Closed suction catheters as part of the ventilator circuit with the same replacement regimen

Use of heat-moisture exchangers

Protective covers for both self-inflating resuscitation bags

Hand hygiene before and after contact with the ventilator or ventilator circuit

\footnotetext{
* Proton pump inhibitors increase gastric $\mathrm{pH}$ and facilitate bacterial growth that enhances bacterial load of gastric fluids. Prophylaxis with sucralfate recommended (ie. does not raise gastric $\mathrm{pH}$ ). $\mathrm{VAP}=$ ventilator-associated pneumonia

$\mathrm{ETT}=$ endotracheal tube

$\mathrm{PVC}=$ polyvinyl chloride
}

Group, and Infectious Disease Societies to develop a more credible VAP definition to monitor hospital performance. ${ }^{2}$ The result was our current ventilator-associated events (VAEs) model, ${ }^{3}$ which shifted the emphasis of surveillance monitoring from VAP to secondary pulmonary complications arising in mechanically ventilated patients.

This narrative review examines whether ventilator bundles designed to reduce VAP remain relevant in the VAE era. It will begin by examining the rationale and evidence upon which various bundle components are based. It provide a brief description of the VAE model, review studies that examined the impact of VAP ventilator bundles on VAE, and evaluate how new iterations of ventilator bundles might reduce VAEs.

\section{The Generic Ventilator Bundle}

Ventilator bundles are standardized practices based upon evidence of varying quality. ${ }^{4}$ Although they differ in components, most include core practices such as semi-recumbent positioning, oral care, avoidance of nasogastric tubes, limited use of orogastric tubes, and strategies to limit the duration of mechanical ventilation by incorporating daily sedation interruptions (DSI) and spontaneous breathing trials (SBT) (Table 1). Some bundles include specialized endotracheal tube(s) (ETT) with subglottic suctioning and/or modified cuff design to reduce microaspiration of orogastric secretions or "closed" ETT suction systems, and protocols to reduce or eliminate routine ventilator circuit changes. Although often not explicitly stated, ventilator 
bundles assume strict adherence to hand hygiene. Finally, while seemingly unrelated to VAP, ventilator bundles also have included standardized practices for prophylaxis of stress ulcers and deep vein thrombosis.

\section{Patient Positioning}

Gastroesophageal reflux is related to frequent occurrences of lower esophageal sphincter relaxation and commonly occurs while supine. ${ }^{5}$ Positive pressure gradients between the gastric and esophageal compartments (ie, intra-abdominal vs intrathoracic) facilitate reflux that is magnified further by gastric distention, ${ }^{6}$ compression by abdominal viscera, ${ }^{7}$ and intra-abdominal hypertension. ${ }^{8}$ Regardless of size, the presence of any gastric tube enhances reflux by stenting open the lower esophageal sphincter. ${ }^{9}$

In the past, mechanically ventilated patients often were kept supine and frequently had nasogastric tubes in place. A seminal study found that this was associated with higher incidences of orogastric secretion aspiration, microbial colonization, and VAP compared to semi-recumbent positioning at a $45^{\circ}$ angle..$^{10,11}$ Enteral feedings also are associated with VAP, ${ }^{12}$ such that being in the supine position while feeding magnifies the incidence of VAP. ${ }^{10}$ Yet, sustained positioning at $45^{\circ}$ was found impractical compared to positioning at $25-30^{\circ} .{ }^{9}$ In addition, nasogastric tubes are associated with sinusitis, ${ }^{13}$ and this is enhanced substantially when an ETT is present. ${ }^{14,15}$ Sinusitis itself substantially increases the risk of VAP (odds ratio 3.66 [interquartile range (IQR)1.81-7.37]). ${ }^{15}$

The most recent systematic review comparing supine positioning with semi-recumbent positioning found no difference in clinically suspected or microbiologically confirmed VAP between positioning at $45^{\circ}$ versus $25-30^{\circ}$ (relative risk 0.74 [IQR 0.35-1.56] and 0.61 [IQR $0.20-$ 1.84], respectively). ${ }^{16}$ Although inter-study heterogeneity and bias risk found in this study (as well as another systematic review) ${ }^{17}$ do not provide a conclusive answer, it is apparent that, unless contraindicated, all patients should be positioned semi-recumbent at $\geq 25^{\circ}$.

An alternative strategy to reduce VAP is placing patients in the lateral horizontal position. ${ }^{18}$ This reduces microaspiration by limiting pooling above the ETT cuff and removes gravitational forces favoring distal migration of any aspirated secretions. A variation of this technique is adding Trendelenburg positioning to enhance secretion movement cephalad.

Two preclinical trials of lateral horizontal-Trendelenburg position found reduced bacterial counts both in the ETT and lower airways compared to the head-up position, ${ }^{19}$ and zero versus $75 \%$ incidence of pneumonia, respectively $(P=.007){ }^{20}$ In a small clinical trial, pepsin levels in tracheal aspirates, which is a signifier for aspi- ration of orogastric secretions, were not different between subjects positioned lateral horizontal versus semi-recumbent at $\geq 30^{\circ} .{ }^{18}$ A large prospective, multi-center, randomized controlled trial (RCT) found that lateral horizontal-Trendelenburg position reduced VAP compared to semi-recumbent position $(0.05 \%$ vs $4.0 \%, P=.04)$. However, the study was terminated early for poor enrollment due to low incidence of VAP. Moreover, the lateral horizontal-Trendelenburg position was associated with serious adverse events compared to semi-recumbent positioning $(6 \%$ vs $0 \%, P=.01) .^{21}$

Therefore, current evidence suggests no advantage but indicates increased risk of adverse effects with lateral horizontal positioning versus semi-recumbent positioning without further benefit in reducing VAP.

\section{ETT Design and Related Ancillary Practices}

Modified ETT designs and ancillary techniques are used to prevent microaspiration of orogastric secretions around the ETT cuff, to prevent bacterial colonization of the ETT, to remove pathogenic biofilm from the ETT lumen, and to regulate ETT cuff pressure. The pathophysiologic rationale is that VAP emanates either from chronic microaspiration of secretions pooled above the ETT cuff $^{22}$ or from pathogenic organisms in biofilm that accumulates inside the ETT. ${ }^{23}$

Pooled subglottic secretions cannot be removed by suctioning the oral cavity. To adequately seal the airway, polyvinyl chloride ETT cuffs require a diameter greater than the trachea. ${ }^{24}$ This interface mismatch between cuff and tracheal wall forms longitudinal folds or "micro-channels" that facilitate seepage of infected orogastric secretions into the lungs. ${ }^{25}$ Evacuating subglottic secretions require specialized ETTs with an imbedded suction channel terminating above the cuff. Several meta-analyses of RCTs testing subglottic drainage ETTs found a substantial reduction in VAP ranging between $42-54 \%$. $^{26-28}$

ETT cuffs made with thin polyurethane form fewer microchannels and appear to perform better in preventing fluid leakage. ${ }^{29}$ ETTs with tapered or conical cuffs conform better with the shape of the trachea and can reduce microaspiration. ${ }^{30}$ However, despite laboratory studies demonstrating reduced leakage with polyurethane cuffs, this has not necessarily reduced VAP risk. ${ }^{31,32}$ Likewise, tapered and conical cuffs have not reduced VAP compared to standard ETT cuffs. ${ }^{31}$

Under-inflated ETT cuffs producing insufficient cuff pressures (ie, $\leq 20 \mathrm{~cm} \mathrm{H}_{2} \mathrm{O}$ ) are independently associated with VAP. ${ }^{33}$ In relatively small, single-center trials, continuous control of cuff pressures between $20-30 \mathrm{~cm} \mathrm{H}_{2} \mathrm{O}$ reduced VAP by approximately $50-60 \% .33,34$ Currently, 2 large, multi-center RCTs are underway to examine 
whether continuous versus intermittent monitoring and control of ETT cuff pressure reduces VAP. ${ }^{35,36}$

Colonization (particularly by multi-drug resistant pathogens) of biofilm in the ETT lumen is another source of VAP. Two strategies that address this problem are preventing colonization by impregnating ETTs with silver or other antimicrobial agents, or by periodically removing biofilm from the internal lumen of the ETT with a scraping device.

Silver possesses broad-spectrum antimicrobial properties when nanoparticles are incorporated into various medical products. ${ }^{37}$ The bactericidal mechanism is the slow release of silver cations that disrupt bacterial cell walls. A systematic review found that silver-coated ETTs significantly reduced VAP risk (relative risk 0.64 [IQR 0.430.96]) and delayed onset of VAP (hazard ratio 0.55 [IQR $0.37-0.84]) .{ }^{38}$

Removing biofilm from the ETT was introduced in $2005,{ }^{39}$ and a subsequent small study reported lower bacterial colonization compared to that found with usual care practice ( $8 \%$ vs $83 \%$ respectively, $P<.001$ ). ${ }^{40}$ However, a larger study found no difference in bacterial counts between routinely cleaned ETTs versus usual care practices. ${ }^{41}$ To date, no studies have demonstrated that removing biofilm reduces the incidence of VAP.

In summary, strong evidence supports subglottic drainage to reduce VAP, whereas compelling evidence for using ETT cuffs made with altered shapes or materials is lacking. Continuous monitoring and control of ETT cuff pressure to reduce VAP awaits results from ongoing large RCTs. Silver-coated ETTs appear to reduce the incidence of VAP, whereas evidence to support biofilm removal from the ETT to reduce VAP currently is lacking.

\section{Reducing the Duration of Mechanical Ventilation}

VAP risk rises with increasing mechanical ventilation duration. ${ }^{42}$ The majority of VAP cases $(62-73 \%)$ are "late onset" (ie, occurring at $>4 \mathrm{~d}$ ), with the highest risk occurring between days 6 and $8 .^{4}$ Thus, identifying patients early who no longer need mechanical ventilation may reduce VAP. Strategies that might accomplish this are restricting sedative use (ie, DSI or targeted light sedation practices), ${ }^{43,44}$ and either $\mathrm{SBT}^{45}$ or early extubation to noninvasive ventilation in select patients. ${ }^{46}$

Historically, $40-50 \%$ of mechanical ventilation duration was devoted to weaning. ${ }^{47}$ Studies from the mid- to late 1990s reported traditional weaning practices added $5.7 \pm 3.7$ to $9.3 \pm 8 \mathrm{~d}$ compared to SBT. ${ }^{48}$ Approximately $80 \%$ of subjects passed their initial SBT, and only $13 \%$ failed subsequent extubation within $48 \mathrm{~h} .{ }^{47}$ SBT reduced weaning by $1-2 \mathrm{~d}^{49}$ and mechanical ventilation by $1.5 \mathrm{~d}$ compared to usual care practices. ${ }^{50}$ Likewise, DSI reduced median mechanical ventilation by $2.4 \mathrm{~d},{ }^{44}$ whereas tar- geted light sedation decreased it by 1.2-2.6 d. ${ }^{51}$ Combining SBT with DSI increased mean ventilator-free days by 3.1 d. ${ }^{43}$

Nonetheless, evidence regarding the impact of DSI and SBT on VAP is scant, and when reported it mostly comes from studies in which VAP was a secondary outcome. Only a small RCT of DSI versus usual care used VAP as a primary end point. ${ }^{52}$ By study day 5 , the incidence of VAP was lower in subjects treated with DSI compared to those treated with usual care $(27.5 \%$ vs $55.3 \%$ respectively, $P<.05$ ). A prospective time-series study of a sedation protocol was associated with reduced median mechanical ventilation duration (4.2 d [IQR 2.1-9.5] vs 8.0 [IQR 2.2-22.0] d, $P=.001$ ) and VAP (hazard ratio 0.81 [IQR 0.62-0.95], $P=.03$ ) compared to physiciandirected practice. ${ }^{53} \mathrm{~A}$ post hoc analysis of the seminal DSI study ${ }^{44}$ found median mechanical ventilation duration was lower in subjects randomized to DSI versus usual care practices (4.8 [IQR 2.9-8.0] vs 7.3 [IQR 3.4-16.1] d, respectively, $P=.003) .{ }^{54}$ However, VAP incidences between the 2 treatment arms (3.0\% vs $8.3 \%$, respectively) were not significant (odds ratio 0.34 [IQR $0.06-1.84$ ], $P=.26)$.

The only large RCT of SBT weaning that reported VAP found a trend toward reduced VAP only in trauma-surgical subjects (6\% vs $19 \%$ in the control arm, $P=.061)$ and no discernable impact in medical subjects. ${ }^{55}$ This occurred despite a significant decrease in median mechanical ventilation ( $2.8 \mathrm{vs} 5.2 \mathrm{~d}$ in the control arm, $P<.001$ ). A large time-series study of an SBT weaning protocol found that mechanical ventilation duration and VAP cases had decreased between the pre- and post-implementation periods $(5.0 \pm 4.3$ vs $3.0 \pm 4.7 \mathrm{~d}, P<.001$; and $15 \%$ vs $5 \%$, $P<.001$, respectively). ${ }^{56}$

In a prospective study of early extubation to noninvasive ventilation versus traditional weaning and extubation practices, early extubation was associated with reduced mechanical ventilation duration (4.0 [IQR 3.0-7.0] d vs 5.5 [IQR 4.0-9.0] d, respectively, $P=.004$ ) and lower incidences of VAP and ventilator-associated tracheobronchitis (9\% vs $25 \%$ respectively, $P=.02$ ). ${ }^{57}$

In summary, DSI and SBT protocols substantially reduce mechanical ventilation duration, but not necessarily VAP. This likely reflects the confounding influence of "early-onset" VAP (ie, 48-96 h after intubation), which represents $25-40 \%$ of all cases. Without a well-designed and sufficiently powered RCT with VAP as the primary outcome, the ability to control or account for non-modifiable risk factors (eg, poor dental health, malnutrition, trauma, ARDS, chronic heart or renal failure, and acute multi-organ failure $)^{4,58}$ will stymie our ability to ascertain whether these practice improvements actually reduce incidence of VAP. 


\section{Ancillary Respiratory Care Practices}

In 1965, the term "respirator lung" described ventilatoracquired, (predominantly) Gram-negative bronchopneumonia. This often progressed to intractable respiratory failure $^{59}$; this was soon recognized as ARDS. ${ }^{60}$ Infectioncontrol deficiencies were identified as likely sources, including non-sterile suction technique and supplies, nonsterilized ventilator circuits, and condensation build-up in ventilator hoses. Correcting these deficiencies (including sterilized ventilator circuits with frequent changes) reportedly eliminated the syndrome.

Beginning in the mid-1980s, the relationship between ventilator circuit and suctioning practices and VAP were again examined. ${ }^{61}$ Reducing circuit changes from every $24 \mathrm{~h}$ to every $48 \mathrm{~h}$ reduced VAP by $50 \%(P=.02),{ }^{62}$ while reductions from every $48 \mathrm{~h}$ to every $7 \mathrm{~d}$ either reduced VAP risk further ${ }^{63}$ or had no impact. ${ }^{64}$ In addition, not changing the ventilation circuit altogether (unless it was visibly soiled) had no impact on VAP compared to routine changes every 7 d. ${ }^{65,66}$

Heat-moisture exchangers ("passive humidification") and heated wire circuits for "active humidification" were designed to reduce bacterial colonization by eliminating condensation within the circuit. ${ }^{61,67}$ Although ventilator circuits typically are contaminated by the same organisms colonizing the patient's lungs, ${ }^{68}$ condensation nevertheless provides a medium for bacterial growth. Unaffected by antibiotic therapy this microbial reservoir is a persistent source for pulmonary reinoculation. However, convincing evidence that these strategies are superior to active humidification alone in reducing VAP remains elusive. ${ }^{67-70}$

Open endotracheal suctioning may cause VAP as disconnecting the circuit increases the risk of inadvertent contamination as it (or the manual resuscitator) often comes into contact with the bed; or the ETT may become colonized accidentally by a contaminated suction catheter. ${ }^{71}$ Closed catheter systems obviate these potential sources. Although closed systems are at higher risk for bacterial contamination (typically by the patient's infected secretions $)^{68}$ than open systems, ${ }^{72-74}$ this has not translate into increased VAP risk. ${ }^{72-76}$

\section{Oral Care}

During critical illness, the stomach often becomes colonized with Gram-negative bacteria. ${ }^{77}$ Frequent gastroesophageal reflux causes the oral cavity to be colonized with these and other pathogenic microorganisms (eg, Streptococcus species, Candida albicans). In VAP, the same bacteria often are isolated from both the oral cavity and sputum. ${ }^{77-80}$ In addition, preexisting dental disease is associated with both community-acquired and hospital-acquired pneumonia. ${ }^{81}$
Oral care practices for VAP prophylaxis include oral swabs, tooth brushing, and rinses with normal saline, providone iodine, or chlorhexidine. In systematic reviews, oral care with chlorhexidine solution or gel reduces VAP risk by $25 \%$ to $40 \%$, with uncertain or no additional benefit from augmenting oral care with tooth brushing. ${ }^{82,83}$

\section{Hand Hygiene}

Several time-series studies underscore the importance of hand hygiene in reducing VAP. Of these, Rello et al ${ }^{65}$ reported reduced VAP risk (odds ratio 0.35 [IQR 0.11 $0.68]$. Introducing oral care and hand hygiene measures alone reduced early-onset VAP by $59 \%$ and was inversely proportional to clinician compliance. ${ }^{84}$ Body-worn hand gel devices reduced VAP from 6.9 cases $/ 1,000 \mathrm{~d}$ to 3.7 cases $/ 1,000 \mathrm{~d}$ of mechanical ventilation $(P<.1) .{ }^{85} \mathrm{In}$ another study, hand hygiene alone reduced all respiratory tract infections by 36.3 infections/1,000 device days. ${ }^{86}$

\section{Stress Ulcer and Deep Vein Thrombosis Prophylaxis and VAP}

Critical illness increases the risk for stress ulcers and deep vein thrombosis. Prophylaxis for each is included in ventilator bundles despite no direct association with VAP risk. Most drugs used for stress ulcer prophylaxis reduce gastrointestinal bleeding by increasing gastric $\mathrm{pH} .{ }^{87} \mathrm{How}-$ ever, this promotes bacterial colonization and is associated with increased VAP risk. ${ }^{88,89}$ Therefore, VAP prophylaxis has recommended sucralfate because it does not increase gastric $\mathrm{pH} .{ }^{90}$ Despite its greater effectiveness in reducing VAP compared to other agents, sucralfate is less effective in reducing gastrointestinal bleeding. ${ }^{88}$

These unrelated prophylactic therapies likely were included in the ventilator bundle to promote sucralfate in reducing VAP risk; whereas their inclusion also was likely viewed as an opportunity to expand the scope of bundled therapies to reduce overall morbidity and mortality. And now the VAE model, with its shifting emphasis from VAP to generalized deterioration in pulmonary function associated with mechanical ventilation, may present another opportunity for improving and monitoring critical care practices that might enhance patient-centered outcomes.

\section{The VAE Model}

In the VAE model, VAP is delimited to patients whose oxygenation is stable or improving over a 2 -d period, who then experience sustained deterioration (Table 2). The initial criterion, ventilator-associated condition (VAC), is based on reasonable thresholds for escalating $\mathrm{F}_{\mathrm{IO}_{2}}$ or PEEP, which in turn is sustained for an additional $2 \mathrm{~d}$. These prerequisites hypothetically filter out transient oxygenation 
Table 2. The VAE Model and Its Relationship to VAP

\begin{tabular}{|c|c|c|c|}
\hline Step & Name & Category and Implication & Criteria \\
\hline 1 & Baseline period & None & $\begin{array}{l}\geq 2 \mathrm{~d} \text { of sustained mechanical ventilation characterized as stable or } \\
\text { improving oxygenation, specifically no increase in either the } \\
\text { minimum } \mathrm{F}_{\mathrm{IO}_{2}} \text { or PEEP in the } 2 \mathrm{~d} \text { prior to deterioration in } \\
\text { oxygenation. }\end{array}$ \\
\hline 2 & VAC & $\begin{array}{l}\text { VAE; potentially publicly } \\
\text { reportable event }\end{array}$ & $\begin{array}{l}\text { On or after day 3: the required minimum settings to maintain } \\
\quad \text { adequate oxygenation increases for } \mathrm{F}_{\mathrm{IO}_{2}} \geq 0.20 \text { and/or PEEP } \\
\quad \geq 3 \mathrm{~cm} \mathrm{H}_{2} \mathrm{O} \\
\text { Sustained increase for additional } 2 \mathrm{~d}\end{array}$ \\
\hline 3 & IVAC & $\begin{array}{l}\text { VAE; potentially publicly } \\
\text { reportable event }\end{array}$ & $\begin{array}{l}\text { On or after day 3: deterioration in oxygenation also is associated } \\
\text { with signs of infection: } \\
\text { Temperature }<36^{\circ} \mathrm{C} \text { or }>38^{\circ} \mathrm{C} \text { or } \mathrm{WBC}<4 \text { or } \\
>12 \times 10^{3} \text { cells } / \mathrm{mm}^{3} \\
\text { Initiation or additional antibiotic therapy with } \pm 2 \mathrm{~d} \text { of VAC } \\
\text { Antibiotic therapy sustained for }>4 \text { qualifying antimicrobial } \\
\text { days }\end{array}$ \\
\hline 4 & Possible VAP & $\begin{array}{l}\text { Internal infection control and/or } \\
\text { quality assurance monitoring }\end{array}$ & $\begin{array}{l}\text { On or after day 3: IVAC and one of the following: } \\
\text { Positive culture indicating a potentially pathogenic organism } \\
\leq 2 \text { calendar days before or after VAC onset* }+ \text { culture } \\
\text { meeting quantitative or corresponding semi-quantitative } \\
\text { threshold for endotracheal aspirate }\left(\geq 10^{5} \mathrm{CFU} / \mathrm{mL}\right) \text {, BAL } \\
\left.\text { fluid or lung tissue ( } \geq 10^{4} \mathrm{CFU} / \mathrm{mL}\right) \text {, or PSB }\left(\geq 10^{3} \mathrm{CFU} /\right. \\
\mathrm{mL}) \text {. } \\
\text { Purulent secretions defined as emanating from lungs } \\
\text { containing } \geq 25 \text { neutrophils and } \leq 10 \text { epithelial cells per low- } \\
\text { power field }(\times 1,000) \text { and organisms identified from the } \\
\text { specimens listed above. } \\
\text { Positive test results for an organism identified from pleural } \\
\text { fluid (via thoracentesis), lung histopathology, or Legionella } \\
\text { species or viruses (eg, parainfluenza, respiratory syncytial } \\
\text { virus). }\end{array}$ \\
\hline
\end{tabular}

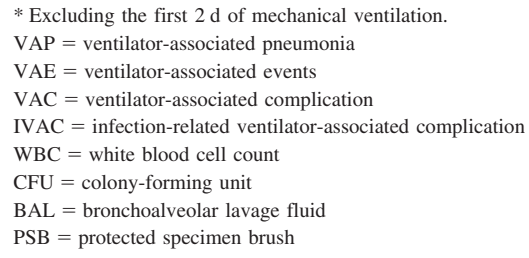

problems caused by readily reversible, non-infectious sources (eg, atelectasis, fluid overload, mucus plugging).

The second criterion, infection-related ventilator-associated complication (IVAC), occurs when VAC coincides with quantifiable signs of infection. Both VAC and IVAC constitute a VAE. Surveillance criteria for VAP are met only when IVAC criteria coincides with sputum or bronchoalveolar fluid samples meeting thresholds for neutrophils and positive cultures for potentially pathogenic organisms. Originally distinguished into "possible" or "probable" VAP (based on culture technique), they were later simplified as "possible VAP" (PVAP). ${ }^{91}$

At some point, VAE surveillance (excluding VAP) may be used for public reporting. ${ }^{92}$ The shift in focus to deteriorating lung function in mechanically ventilated patients was intended to make VAE surveillance as objective as possible, so as to facilitate automation and improve comparability between institutions..$^{93}$ When coupled with severity of illness scores, tracking VAE might allow for credible risk adjustments when hospitals are benchmarked against one another. ${ }^{93}$

\section{Ventilator Bundle Impact on VAE}

To date, 6 studies ${ }^{94-99}$ have examined the impact of ventilator bundles on VAE; of these, 5 were retrospective studies (Table 3). A recent meta-analysis examined the impact of ventilator bundles on mortality. ${ }^{100}$ Initial studies

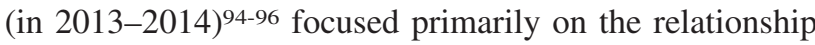
between VAC, IVAC, and VAP, not the impact of ventilator bundles on VAE. These studies had 4 common 


\section{Ventilator Bundles in Transition}

Table 3. Impact of the Ventilator Bundle on VAE Incidence

\begin{tabular}{|c|c|c|}
\hline Study/Design Setting and Objective(s) & Bundle Characteristics & Major Findings \\
\hline Ding et al 201394 & DSI & $\begin{array}{l}\text { Formal adoption of a ventilator bundle did not impact the incidence of } \\
\text { VAC, IVAC, or VAE-VAP }\end{array}$ \\
\hline $\begin{array}{l}\text { Retrospective, single-center, time-series } \\
\text { study }\end{array}$ & Oral care with chlorhexidine & Potential explanations include: \\
\hline $\begin{array}{l}\text { All adults undergoing mechanical } \\
\text { ventilation for } \geq 48 \mathrm{~h} \text { over } 72 \text { months }\end{array}$ & HOB elevation & $\begin{array}{l}\text { Very low pre-post incidence of VAE: VAC ( } 11 \% \text { vs } 11 \%) \text {, IVAC } \\
(3 \% \text { vs } 4 \%) \text {, and probable or possible VAP }(1 \% \text { vs } 4 \%)\end{array}$ \\
\hline$N=684$ subjects & SBT & $\begin{array}{l}\text { Bundle adherence is unknown because ventilator bundle } \\
\text { components (eg, SBT and DSI) were already used ad hoc during } \\
\text { the pre-implementation period, albeit with inadequate } \\
\text { documentation }\end{array}$ \\
\hline $\begin{array}{l}\text { The incidence and outcome of VAP (using } \\
\text { multiple definitions including VAE) } \\
\text { before and after introduction of the } \\
\text { ventilator bundle }\end{array}$ & Stress ulcer prophylaxis & \\
\hline Muscedere et al $2013^{95}$ & DSI & $\begin{array}{l}\text { Increased bundle compliance associated with decreased incidence of } \\
\text { VAC but not IVAC }\end{array}$ \\
\hline $\begin{array}{l}\text { Retrospective, multi-center, time-series } \\
\text { study }\end{array}$ & Oral care with chlorhexidine & $\begin{array}{l}\text { Over 24-month study period, adherence with several elements } \\
\text { improved substantially but likely insufficiently for accurate } \\
\text { assessment of the full potential for prophylaxis (eg, HOB elevation } \\
\text { increased from } 29 \% \text { to } 41 \% \text {; oral care with chlorhexidine increased } \\
\text { from } 16 \% \text { to } 50 \% \text {, SSD increased from } 36 \% \text { to } 58 \% \text { ) }\end{array}$ \\
\hline $\begin{array}{l}11 \text { North American adult ICUs over } \\
24 \text { months }\end{array}$ & HOB elevation & $\begin{array}{l}\text { There was a trend toward decreased incidence of VAC and IVAC } \\
\text { associated with an increased \% of days with DSI and SBT } \\
\text { performed }\end{array}$ \\
\hline$N=1,320$ subjects & SBT & DSI: OR 0.93 (IQR $0.87-1.00), P=.05$ \\
\hline \multirow{2}{*}{$\begin{array}{l}\text { To assess the impact of the ventilator } \\
\text { bundle on incidence of VAE }\end{array}$} & SSD & SBT: OR 0.97 (IQR 0.94-1.01), $P=.10$ \\
\hline & & $\begin{array}{l}\text { Subjects with either VAC or IVAC tended to have undergone } \\
\text { nasotracheal intubation }\end{array}$ \\
\hline Lewis et al $2014^{96}$ & DSI & $\begin{array}{l}\text { Multivariate logistic regression modeling revealed that none of the } \\
\text { bundle elements was associated with either VAC or IVAC }\end{array}$ \\
\hline $\begin{array}{l}\text { Retrospective single-center case-control } \\
\text { study }\end{array}$ & DVT prophylaxis & $\begin{array}{l}\text { The relationship between positive fluid balance (per L) and VAC } \\
\text { approached significance: OR } 1.2 \text { (IQR 1.0-1.4) }\end{array}$ \\
\hline All ICUs studied over a 12-month period & Oral care with chlorhexidine & \\
\hline $\begin{array}{l}N=220 \text { subjects }(100 \text { case subjects; } \\
110 \text { control subjects })\end{array}$ & HOB elevation & \\
\hline \multirow{2}{*}{$\begin{array}{l}\text { To identify risk factors for VAC and } \\
\text { IVAC }\end{array}$} & Stress ulcer prophylaxis & \\
\hline & SBT & \\
\hline Klompas et al $2016^{97}$ & DSI & DSI associated with: \\
\hline $\begin{array}{l}\text { Retrospective, single-center, observational } \\
\text { cohort study }\end{array}$ & DVT prophylaxis & $\begin{array}{l}\text { Decreased time to extubation: hazard ratio } 1.81 \text { (IQR 1.54-2.12), } \\
\quad P<.001\end{array}$ \\
\hline $\begin{array}{l}\text { All subjects undergoing mechanical } \\
\text { ventilation for }>3 \mathrm{~d} \text { over } 48 \text { months }\end{array}$ & Oral care with chlorhexidine & $\begin{array}{l}\text { Decreased mortality risk during mechanical ventilation: hazard ratio } \\
0.51 \text { (IQR } 0.38-0.68), P<.001\end{array}$ \\
\hline$N=5,539$ subjects & HOB elevation & SBT associated with: \\
\hline \multirow{11}{*}{$\begin{array}{l}\text { To evaluate the impact of the ventilator } \\
\text { bundle and its individual elements with } \\
\text { the incidence of VAE, mechanical } \\
\text { ventilation duration, hospital length of } \\
\text { stay, and hospital mortality }\end{array}$} & Stress ulcer prophylaxis & $\begin{array}{l}\text { Decreased time to extubation: hazard ratio } 2.48 \text { (IQR 2.23-2.76), } \\
P<.001\end{array}$ \\
\hline & SBT & $\begin{array}{l}\text { Decreased risk for VAE: hazard ratio } 0.55 \text { (IQR } 0.40-0.76 \text { ), } \\
P<.001\end{array}$ \\
\hline & & $\begin{array}{l}\text { Decreased mortality risk: hazard ratio } 0.28 \text { (IQR } 0.20-0.38 \text { ), } \\
P=.001\end{array}$ \\
\hline & & HOB elevation associated with: \\
\hline & & $\begin{array}{l}\text { Decreased time to extubation: hazard ratio } 1.38 \text { (IQR 1.14-1.68), } \\
\quad P<.001\end{array}$ \\
\hline & & DVT prophylaxis associated with: \\
\hline & & $\begin{array}{l}\text { Decreased time to extubation: hazard ratio } 2.57 \text { (IQR 1.80-3.66), } \\
P<.001\end{array}$ \\
\hline & & Oral care with chlorhexidine associated with: \\
\hline & & $\begin{array}{l}\text { Increased mortality risk during mechanical ventilation: hazard ratio } \\
1.63 \text { (IQR } 1.15-2.31), P=.006\end{array}$ \\
\hline & & Stress ulcer prophylaxis associated with: \\
\hline & & Increased VAP risk: hazard ratio 7.69 (IQR $1.44-41.10), P=.02$ \\
\hline
\end{tabular}


Table 3. Continued

\begin{tabular}{|c|c|c|}
\hline Study/Design Setting and Objective(s) & Bundle Characteristics & Major Findings \\
\hline O'Horo et al $2016^{98}$ & DSI & $\begin{array}{l}\text { Oral care with chlorhexidine was the only bundle element associated } \\
\text { with VAE: hazard ratio } 0.44 \text { (IQR } 0.26-0.77)^{*}\end{array}$ \\
\hline $\begin{array}{l}\text { Retrospective, single-center, } \\
\text { observational cohort study }\end{array}$ & DVT prophylaxis & $\begin{array}{c}\text { Adherence with stress ulcer prophylaxis had a borderline association } \\
\text { with increased VAE risk: hazard ratio } 1.59 \text { (IQR } 1.00-2.50)^{*}\end{array}$ \\
\hline $\begin{array}{l}\text { All adult ICUs studied over } \\
31 \text { months }\end{array}$ & Oral care with chlorhexidine & \\
\hline$N=2,660$ subjects & Stress-ulcer prophylaxis & \\
\hline $\begin{array}{l}\text { To evaluate the incidence of VAE } \\
\text { within } 2 \mathrm{~d} \text { of failure to meet any } \\
\text { bundle element }\end{array}$ & & \\
\hline Harris et al $2018^{99}$ & HOB elevation $30-45^{\circ}$ & $\begin{array}{l}\text { No difference between bundle scores in VAE cases vs. controls } 3 \mathrm{~d} \\
\text { prior to VAE onset: } 0.73 \text { and } 0.70 \text {, respectively }\end{array}$ \\
\hline $\begin{array}{l}\text { Prospective, single-center } \\
\text { observational case-control study } \\
\text { (ratio of } 1: 4 \text {, respectively) }\end{array}$ & SBT: daily assessment & OR $1.15, P=.34$ \\
\hline$n=273$ cases $n=1,092$ controls & Targeted sedation by RASS & $\begin{array}{l}\text { No difference in oral care score between VAE cases and controls } 3 \\
\text { days prior to VAE onset }\end{array}$ \\
\hline \multirow{6}{*}{$\begin{array}{l}\text { To determine whether decreased } \\
\text { adherence with the ventilator bundle } \\
\text { increased VAE risk }\end{array}$} & Oral care with chlorhexidine & OR $1.13, P=.38$ \\
\hline & & $\begin{array}{l}\text { Oral care with chlorhexidine: only variable associated with increased } \\
\text { VAE risk for all subjects: }\end{array}$ \\
\hline & & At $3 \mathrm{~d}$ mechanical ventilation: $\mathrm{OR} 1.45, P=.007$ \\
\hline & & At $\geq 7 \mathrm{~d}$ mechanical ventilation: $\mathrm{OR} 1.42, P=.03$ \\
\hline & & With IVAC and PVAP: OR $1.73, P=.0006$ \\
\hline & & And in multivariate analysis: OR $1.45, P=.008$ \\
\hline \multicolumn{3}{|l|}{ * Adjusted for APACHE III and gender. } \\
\hline \multicolumn{3}{|l|}{$\mathrm{VAE}=$ ventilator-associated event } \\
\hline \multicolumn{3}{|l|}{ DSI $=$ daily sedation interruption } \\
\hline \multirow{2}{*}{\multicolumn{3}{|c|}{$\begin{array}{l}\mathrm{VAC}=\text { ventilator-associated condition } \\
\text { IVAC }=\text { infection-related ventilator-associated condition }\end{array}$}} \\
\hline & & \\
\hline \multicolumn{3}{|c|}{$\begin{array}{l}\text { IVAC }=\text { infection-related ventilator-associated condition } \\
\text { VAP }=\text { ventilator-associated pneumonia }\end{array}$} \\
\hline \multicolumn{3}{|l|}{$\mathrm{HOB}=$ head of bed } \\
\hline \multicolumn{3}{|l|}{$\mathrm{SBT}=$ spontaneous breathing trial } \\
\hline \multicolumn{3}{|l|}{ SSD $=$ subglottic secretion drainage } \\
\hline \multicolumn{3}{|l|}{$\mathrm{OR}=$ odds ratio } \\
\hline \multicolumn{3}{|l|}{$\mathrm{IQR}=$ interquartile range } \\
\hline \multicolumn{3}{|l|}{ DVT $=$ deep vein thrombosis } \\
\hline RASS $=$ Richmond Agitation-Sedation Scale & & \\
\hline
\end{tabular}

bundle components: head of bed elevation, oral care with chlorhexidine, DSI, and SBT.

Ding et $\mathrm{al}^{94}$ found no difference in VAC or IVAC before or after bundle implementation, yet the overall incidence of VAE was low; the investigators noted that many of the bundle components already were practiced ad hoc (prior to formal implementation), but their use was poorly documented. Muscedere et al ${ }^{95}$ found increased bundle adherence was associated with decreased VAC but not IVAC. ${ }^{95}$ However, individual bundle components were not associated with VAC or IVAC in multivariate logistic regression modeling. Interestingly, the percentage of days when stipulated DSI or SBT were performed produced salient trends toward protection from VAC and IVAC. Nevertheless, interpreting these results is limited because of suboptimal bundle compliance. Lewis et al ${ }^{96}$ reported that none of the 6 ventilator bundle components was associated with either VAC or IVAC.

In later studies (in 2016 and 2018), ${ }^{97-99}$ the only common practices were oral care with chlorhexidine and either
DSI or targeted light sedation (both are indistinguishable in their impact on duration of mechanical ventilation). ${ }^{101}$ These studies were substantially larger than the earlier studies (ie, cumulative sample size of 9,564 vs 2,224, respectively), and their results were more informative.

Klompas et $\mathrm{al}^{97}$ reported that DSI, SBT, thrombosis prophylaxis, and semi-recumbent positioning were independently associated with reduced duration of mechanical ventilation. However, only SBT was associated with decreased VAE incidence despite under-performance (ie, 25$33 \%$ of ventilator days that required SBT). They also reported increased mortality risk associated with chlorhexidine, as well as increased VAP risk associated with stress ulcer prophylaxis.

$\mathrm{O}^{\prime}$ Horo et $\mathrm{al}^{98}$ found a salient trend between stress ulcer prophylaxis and VAE risk, and a significant reduction in VAE risk with chlorhexidine. However, interpreting their results is limited because of overall low VAE incidence. The most interesting (and only prospective) study examined VAE incidence within $2 \mathrm{~d}$ of failure to implement any 
bundle element. Harris et a ${ }^{99}$ scored both overall daily and cumulative compliance with the ventilator bundle. They reported no difference between ventilator bundle compliance and the development of VAE. However, oral care with chlorhexidine again was associated with increased VAE risk.

Pileggi et al ${ }^{100}$ reported that ventilator bundle implementation was associated with reduced overall ICU mortality (odds ratio 0.90 [IQR $0.84-0.97]$ ). Moreover, in a subset of studies reporting VAP-related mortality, the ventilator bundle was associated with a considerably larger reduction in mortality risk (odds ratio 0.71 [IQR 0.52 0.97). Despite these promising results, bundle compliance varied widely (20-99.8\%), and the studies themselves were of poor quality.

\section{Barriers and Unresolved Issues}

Common themes that emerged in the discussions of these studies are the impact of non-modifiable risk factors, the impact of individual bundle components on VAE, and uncertainty regarding how ventilator bundle adherence might impact VAE.

Because VAP and VAE are inter-related, non-modifiable risk factors for VAP also likely impact the incidence of VAE and thus ventilator bundle effectiveness. VAP risk is associated with numerous confounding variables such as poverty and homelessness (eg, malnutrition, ubiquitous dental disease), traumatic injuries, and immunosuppression, ${ }^{4}$ as well as previous exposure to antibiotic therapy. ${ }^{102}$

Moreover, what constitutes modifiable versus non-modifiable factors remains unclear. For example, men are at increased risk for developing VAE. ${ }^{98,103}$ Boyer et al ${ }^{104}$ found that only $37 \%$ of VAC instances were preventable, whereas $40 \%$ were attributable to non-infectious sources (eg, ARDS, pulmonary edema, atelectasis). Other risk factors, such as intra-abdominal hypertension and sepsis, are, at best, questionably modifiable. Intra-abdominal hypertension often develops after abdominal trauma, burns, and other conditions, ${ }^{8,105}$ and it is associated with VAP. ${ }^{106}$ The incidence and associated mortality with severe sepsis is related to poverty, ${ }^{105}$ poor access to medical care, ${ }^{107}$ and race. ${ }^{108}$ Therefore, preventing VAE in these subgroups is uncertain, if not unknown.

Another issue is that specific bundle elements, as well as other therapies vital to caring for the critically ill, appear to be at cross purposes with VAP or VAE reduction. Two studies found that stress ulcer prophylaxis was associated (or approached significant association) with increased VAP risk. ${ }^{95,97}$ In addition, enteral feeding increases VAP risk. ${ }^{109,110}$ Both therapies are crucial and therefore must be considered as non-modifiable risk factors for VAP and probably VAE as well.
The greatest concern raised in the reviewed studies (as well as others) is evidence that oral care with chlorhexidine increases both VAE risk ${ }^{99}$ and mortality risk..$^{97,111,112}$ Yet the pathophysiologic mechanism in intubated subjects remains unclear. ARDS following either gross aspiration or inadvertent intravenous administration of chlorhexidine have been documented, ${ }^{113,114}$ as has an animal model demonstrating acute lung injury following intra-tracheal administration. ${ }^{115}$ These reports are mechanistically consistent with an observational study in which mortality risk was restricted to non-intubated subjects. ${ }^{111}$ Moreover, in addition to causing oral mucosa damage and, by extension, lung epithelial injury, chlorhexidine may promote bacterial resistance and accelerate acquired resistance. ${ }^{116} \mathrm{Be}-$ cause chlorhexidine's apparent effectiveness in reducing VAP is limited to unblinded studies, ${ }^{117}$ its continued inclusion in ventilator bundles should be reconsidered.

A particularly intriguing issue was determining the "dosage" or impact of missing bundle components and its window of effect on the incidence of VAE. ${ }^{98}$ For example, we cannot determine the temporal threshold at which positioning of the head of bed below $25^{\circ}$ translates into quantifiable and meaningful VAE risk. The same quandary applies to missing episodes of oral care, DSI, or SBT. There also is the problem of false conclusion bias, ie, that performing a particular bundle element necessarily implies a meaningful reduction in VAE risk. For example, performing an SBT will not impact VAE risk if a positive test does not expeditiously result in an extubation trial (in those without contraindications).

At this juncture, no high-level evidence supports the notion that current ventilator bundles reduce VAE risk. In addition, chlorhexidine and stress ulcer prophylaxis may promote VAE. Even if chlorhexidine prophylaxis is discontinued in the future, stress ulcer prophylaxis will continue regardless of VAE risk. In contrast, reducing mechanical ventilation duration (ie, via DSI, targeted light sedation, or SBT) should remain a central feature of any VAE-prevention bundle.

Moreover, the VAE paradigm presents the opportunity to fashion a more expansive bundle. In one of the reviewed studies, positive fluid balance tended to increase VAC risk (odds ratio 1.2 [IQR 1.0-1.4]). ${ }^{96}$ Both hydrostatic and altered permeability pulmonary edema respond to neutral or negative fluid balance with improved oxygenation and reduced mechanical ventilation duration. ${ }^{52,118-120}$ Therefore, any new iteration of a ventilator bundle for VAE prophylaxis should include conservative fluid management guidelines.

\section{Summary}

Since 2013, only 6 predominantly retrospective studies have examined the utility of ventilator bundles to reduce 


\section{Ventilator Bundles in Transition}

the incidence of VAE, while another examined its impact on mortality. The study findings were collectively inconsistent, and the quality of evidence was insufficient to drive public policy. They do, however, provide the basis for designing future, high-level, prospective studies to determine the potential value of specific bundle elements in reducing the incidence of VAE. At this juncture, and based on limited evidence, DSI and SBT appear to be the factors most likely to reduce VAE.

\section{REFERENCES}

1. Resar R, Pronovost P, Haraden C, Simmonds T, Rainey T, Nolan T. Using a bundle approach to improve ventilator care processes and reduce ventilator-associated pneumonia. Jt Comm J Qual Patient Saf 2005;31(5):243-248.

2. Levy MM. A new definition of ventilator-associated pneumonia: far from perfect, better than before. Ann Am Thorac Soc 2013; 10(6):644-645.

3. Magill SS, Klompas M, Balk R, Burns SM, Deutschman CS, Diekema D, et al. Executive summary: developing a new, national approach to surveillance for ventilator-associated events. Ann Am Thorac Soc 2013;10(6):S220-223.

4. Kallet RH. The vexing problem of ventilator-associated pneumonia: observations on pathophysiology, public policy, and clinical science. Respir Care 2015;60(10):1495-1508.

5. Dent J, Dodds WJ, Friedman RH, Sekiguchi T, Hogan WJ, Arndorfer RC, et al. Mechanism of gastroesophageal reflux in recumbent asymptomatic human subjects. J Clin Invest 1980;65(2):256267.

6. Holloway RH, Hongo M, Berger K, McCallum RW. Gastric distention: a mechanism for postprandial gastroesophageal reflux. Gastroenterology 1985;89(4):779-784.

7. Hebbard GS, Reid K, Sun WM, Horowitz M, Dent J. Postural changes in proximal gastric volume and pressure measured using a gastric barostat. Neurogastroenterol Motil 1995;7(3):169-174.

8. Papakrivou E, Manoulakas E, Zakynthinos E, Makris D. Is intraabdominal hypertension a risk factor for ventilator-associated pneumonia? Ann Transl Med 2018;6(21):419.

9. van Nieuwenhoven CA, Vandenbroucke-Grauls C, van Tiel FH, Joore HC, van Schijndel RJ, van der Tweel I, et al. Feasibility and effects of the semirecumbent position to prevent ventilator-associated pneumonia: a randomized study. Crit Care Med 2006;34(2): 396-402.

10. Torres A, Serra-Batlles J, Ros E, Piera C, Puig de la Bellacasa J, Cobos A, et al. Pulmonary aspiration of gastric contents in patients receiving mechanical ventilation: the effect of body position. Ann Intern Med 1992;116(7):540-543

11. Drakulovic MB, Torres A, Bauer TT, Nicolas JM, Nogue S, Ferrer M. Supine body position as a risk factor for nosocomial pneumonia in mechanically ventilated patients: a randomised trial. Lancet 1999; 354(9193):1851-1858.

12. Artinian V, Krayem H, DiGiovine B. Effects of early enteral feeding on the outcome of critically ill mechanically ventilated medical patients. Chest 2006;129(4):960-967.

13. Salord F, Gaussorgues P, Marti-Flich J, Sirodot M, Allimant C, Lyonnet $\mathrm{D}$, et al. Nosocomial maxillary sinusitis during mechanical ventilation: a prospective comparison of orotracheal versus the nasotracheal route for intubation. Intensive Care Med 1990;16(6): 390-393

14. Metheny NA, Hinyard LJ, Mohammed KA. Incidence of sinusitis associated with endotracheal and nasogastric tubes: NIS database. Am J Crit Care 2018;27(1):24-31.
15. Agrafiotis M, Vardakas KZ, Gkegkes ID, Kapaskelis A, Falagas ME. Ventilator-associated sinusitis in adults: systematic review and meta-analysis. Respir Med 2012;106(8):1082-1095.

16. Wang L, Li X, Yang Z, Tang X, Yuan Q, Deng L, et al. Semirecumbent position versus supine position for the prevention of ventilator-associated pneumonia in adults requiring mechanical ventilation. Cochrane Database Syst Rev 2016(1):CD009946.

17. Alexiou VG, Ierodiakonou V, Dimopoulos G, Falagas ME. Impact of patient position on the incidence of ventilator-associated pneumonia: a meta-analysis of randomized controlled trials. J Crit Care 2009;24(4):515-522.

18. Mauri T, Berra L, Kumwilaisak K, Pivi S, Ufberg JW, Kueppers F, et al. Lateral-horizontal patient position and horizontal orientation of the endotracheal tube to prevent aspiration in adult surgical intensive care unit patients: a feasibility study. Respir Care 2010; 55(3):294-302.

19. Panigada M, Berra L, Greco G, Stylianou M, Kolobow T. Bacterial colonization of the respiratory tract following tracheal intubationeffect of gravity: an experimental study. Crit Care Med 2003;31(3): 729-737.

20. Li Bassi G, Zanella A, Cressoni M, Stylianou M, Kolobow T. Following tracheal intubation, mucus flow is reversed in the semirecumbent position: possible role in the pathogenesis of ventilatorassociated pneumonia. Crit Care Med 2008;36(2):518-525.

21. Li Bassi G, Panigada M, Ranzani OT, Zanella A, Berra L, Cressoni $\mathrm{M}$, et al. Randomized, multicenter trial of lateral Trendelenburg versus semirecumbent body position for the prevention of ventilator-associated pneumonia. Intensive Care Med 2017;43(11):15721584.

22. Jaillette E, Martin-Loeches I, Artigas A, Nseir S. Optimal care and design of the tracheal cuff in the critically ill patient. Ann Intensive Care 2014;4(1):7.

23. Vandecandelaere I, Coenye T. Microbial composition and antibiotic resistance of biofilms recovered from endotracheal tubes of mechanically ventilated patients. Adv Exp Med Biol 2015;830:137155.

24. Dullenkopf A, Gerber A, Weiss M. Fluid leakage past tracheal tube cuffs: evaluation of the new Microcuff endotracheal tube. Intensive Care Med 2003;29(10):1849-1853.

25. Mietto C, Pinciroli R, Patel N, Berra L. Ventilator associated pneumonia: evolving definitions and preventive strategies. Respir Care 2013;58(6):990-1007.

26. Muscedere J, Rewa O, McKechnie K, Jiang X, Laporta D, Heyland DK. Subglottic secretion drainage for the prevention of ventilatorassociated pneumonia: a systematic review and meta-analysis. Crit Care Med 2011;39(8):1985-1991.

27. Caroff DA, Li L, Muscedere J, Klompas M. Subglottic secretion drainage and objective outcomes: a systematic review and metaanalysis. Crit Care Med 2016;44(4):830-840.

28. Mao Z, Gao L, Wang G, Liu C, Zhao Y, Gu W, et al. Subglottic secretion suction for preventing ventilator-associated pneumonia: an updated meta-analysis and trial sequential analysis. Crit Care 2016;20(1):353.

29. Lorente L, Lecuona M, Jimenez A, Mora ML, Sierra A. Influence of an endotracheal tube with polyurethane cuff and subglottic secretion drainage on pneumonia. Am J Respir Crit Care Med 2007; 176(11):1079-1083.

30. Dave MH, Frotzler A, Spielmann N, Madjdpour C, Weiss M. Effect of tracheal tube cuff shape on fluid leakage across the cuff: an in vitro study. Br J Anaesth 2010;105(4):538-543.

31. Rouze A, Jaillette E, Poissy J, Preau S, Nseir S. Tracheal tube design and ventilator-associated pneumonia. Respir Care 2017; 62(10):1316-1323. 


\section{Ventilator Bundles in Transition}

32. Blot SI, Rello J, Koulenti D. The value of polyurethane-cuffed endotracheal tubes to reduce microaspiration and intubation-related pneumonia: a systematic review of laboratory and clinical studies. Crit Care 2016;20(1):203.

33. Rouze A, Jaillette E, Nseir S. Continuous control of tracheal cuff pressure: an effective measure to prevent ventilator-associated pneumonia? Crit Care 2014;18(5):512.

34. Nseir S, Zerimech F, Fournier C, Lubret R, Ramon P, Durocher A, et al. Continuous control of tracheal cuff pressure and microaspiration of gastric contents in critically ill patients. Am J Respir Crit Care Med 2011;184(9):1041-1047.

35. Marjanovic N, Frasca D, Asehnoune K, Paugam C, Lasocki S, Ichai $\mathrm{C}$, et al. Multicentre randomised controlled trial to investigate the usefulness of continuous pneumatic regulation of tracheal cuff pressure for reducing ventilator-associated pneumonia in mechanically ventilated severe trauma patients: the AGATE study protocol. BMJ Open 2017;7(8):e017003.

36. Dat VQ, Geskus RB, Wolbers M, Loan HT, Yen LM, Binh NT, et al. Continuous versus intermittent endotracheal cuff pressure control for the prevention of ventilator-associated respiratory infections in Vietnam: study protocol for a randomised controlled trial. Trials 2018;19(1):217.

37. Marin S, Vlasceanu GM, Tiplea RE, Bucur IR, Lemnaru M, Marin MM, et al. Applications and toxicity of silver nanoparticles: a recent review. Curr Top Med Chem 2015;15(16):1596-1604.

38. Tokmaji G, Vermeulen H, Muller MC, Kwakman PH, Schultz MJ, Zaat SA. Silver-coated endotracheal tubes for prevention of ventilator-associated pneumonia in critically ill patients. Cochrane Database Syst Rev 2015(8):CD009201.

39. Kolobow T, Berra L, Li Bassi G, Curto F. Novel system for complete removal of secretions within the endotracheal tube: the Mucus Shaver. Anesthesiology 2005;102(5):1063-1065.

40. Berra L, Coppadoro A, Bittner EA, Kolobow T, Laquerriere P, Pohlmann JR, et al. A clinical assessment of the Mucus Shaver: a device to keep the endotracheal tube free from secretions. Crit Care Med 2012;40(1):119-124.

41. Pinciroli R, Mietto C, Piriyapatsom A, Chenelle CT, Thomas JG, Pirrone M, et al. Endotracheal tubes cleaned with a novel mechanism for secretion removal: a randomized controlled clinical study. Respir Care 2016;61(11):1431-1439.

42. Charles MP, Kali A, Easow JM, Joseph NM, Ravishankar M, Srinivasan S, et al. Ventilator-associated pneumonia. Australas Med J 2014;7(8):334-344.

43. Girard TD, Kress JP, Fuchs BD, Thomason JW, Schweickert WD, Pun BT, et al. Efficacy and safety of a paired sedation and ventilator weaning protocol for mechanically ventilated patients in intensive care (Awakening and Breathing Controlled trial): a randomised controlled trial. Lancet 2008;371(9607):126-134.

44. Kress JP, Pohlman AS, O'Connor MF, Hall JB. Daily interruption of sedative infusions in critically ill patients undergoing mechanical ventilation. N Engl J Med 2000;342(20):1471-1477.

45. Esteban A, Alia I, Gordo F, Fernandez R, Solsona JF, Vallverdu I, et al. Extubation outcome after spontaneous breathing trials with T-tube or pressure support ventilation. The Spanish Lung Failure Collaborative Group. Am J Respir Crit Care Med 156(2 Pt 1):459465, 1997.

46. Yeung J, Couper K, Ryan EG, Gates S, Hart N, Perkins GD. Noninvasive ventilation as a strategy for weaning from invasive mechanical ventilation: a systematic review and Bayesian meta-analysis. Intensive Care Med 2018;44(12):2192-2204.

47. Boles JM, Bion J, Connors A, Herridge M, Marsh B, Melot C, et al. Weaning from mechanical ventilation. Eur Respir J 2007;29(5): 1033-1056.
48. Brochard L, Rauss A, Benito S, Conti G, Mancebo J, Rekik N, et al. Comparison of three methods of gradual withdrawal from ventilatory support during weaning from mechanical ventilation. Am J Respir Crit Care Med 1994;150(4):896-903.

49. Esteban A, Frutos F, Tobin MJ, Alia I, Solsona JF, Valverdu I, et al. A comparison of four methods of weaning patients from mechanical ventilation. Spanish Lung Failure Collaborative Group. N Engl J Med 1995;332(6):345-350.

50. Ely EW, Baker AM, Dunagan DP, Burke HL, Smith AC, Kelly PT, et al. Effect on the duration of mechanical ventilation of identifying patients capable of breathing spontaneously. N Engl J Med 1996; 335(25): 1864-1869.

51. Hughes CG, Girard TD, Pandharipande PP. Daily sedation interruption versus targeted light sedation strategies in ICU patients. Crit Care Med 2013;41(9 Suppl 1):S39-S45.

52. Shahabi M, Yousefi H, Yazdannik AR, Alikiaii B. The effect of daily sedation interruption protocol on early incidence of ventilatorassociated pneumonia among patients hospitalized in critical care units receiving mechanical ventilation. Iran J Nurs Midwifery Res 2016;21(5):541-546.

53. Quenot JP, Ladoire S, Devoucoux F, Doise JM, Cailliod R, Cunin $\mathrm{N}$, et al. Effect of a nurse-implemented sedation protocol on the incidence of ventilator-associated pneumonia. Crit Care Med 2007; 35(9):2031-2036.

54. Schweickert WD, Gehlbach BK, Pohlman AS, Hall JB, Kress JP. Daily interruption of sedative infusions and complications of critical illness in mechanically ventilated patients. Crit Care Med 2004; 32(6): 1272-1276.

55. Marelich GP, Murin S, Battistella F, Inciardi J, Vierra T, Roby M. Protocol weaning of mechanical ventilation in medical and surgical patients by respiratory care practitioners and nurses: effect on weaning time and incidence of ventilator-associated pneumonia. Chest 2000;118(2):459-467.

56. Dries DJ, McGonigal MD, Malian MS, Bor BJ, Sullivan C. Protocol-driven ventilator weaning reduces use of mechanical ventilation, rate of early reintubation, and ventilator-associated pneumonia. J Trauma 2004;56(5):943-951.

57. Vaschetto R, Longhini F, Persona P, Ori C, Stefani G, Liu S, et al. Early extubation followed by immediate noninvasive ventilation vs. standard extubation in hypoxemic patients: a randomized clinical trial. Intensive Care Med 2019;45(1):62-71.

58. Uvizl R, Kolar M, Herkel T, Vobrova M, Langova K. Possibilities for modifying risk factors for the development of hospital-acquired pneumonia in intensive care patients: results of a retrospective, observational study. Biomed Pap Med Fac Univ Palacky Olomouc Czech Repub 2017;161(3):303-309.

59. Linton RC, Walker FW, Spoerel WE. Respirator care in a general hospital: a five-year survey. Can Anaesth Soc J 1965;12(5):451457.

60. Kallet RH, Matthay MA. Hyperoxic acute lung injury. Respir Care 2013;58(1):123-141.

61. Branson RD. The ventilator circuit and ventilator-associated pneumonia. Respir Care 2005;50(6):774-785.

62. Craven DE, Kunches LM, Kilinsky V, Lichtenberg DA, Make BJ, McCabe WR. Risk factors for pneumonia and fatality in patients receiving continuous mechanical ventilation. Am Rev Respir Dis 1986;133(5):792-796.

63. Fink JB, Krause SA, Barrett L, Schaaff D, Alex CG. Extending ventilator circuit change interval beyond 2 days reduces the likelihood of ventilator-associated pneumonia. Chest 1998;113(2):405411.

64. Hess D, Burns E, Romagnoli D, Kacmarek RM. Weekly ventilator circuit changes: a strategy to reduce costs without affecting pneumonia rates. Anesthesiology 1995;82(4):903-911. 


\section{Ventilator Bundles in Transition}

65. Rello J, Afonso E, Lisboa T, Ricart M, Balsera B, Rovira A, et al. A care bundle approach for prevention of ventilator-associated pneumonia. Clin Microbiol Infect 2013;19(4):363-369.

66. Kollef MH, Shapiro SD, Fraser VJ, Silver P, Murphy DM, Trovillion E, et al. Mechanical ventilation with or without 7-day circuit changes. A randomized controlled trial. Ann Intern Med 1995; 123(3):168-174.

67. Niel-Weise BS, Wille JC, van den Broek PJ. Humidification policies for mechanically ventilated intensive care patients and prevention of ventilator-associated pneumonia: a systematic review of randomized controlled trials. J Hosp Infect 2007;65(4):285-291.

68. Hess DR, Kallstrom TJ, Mottram CD, Myers TR, Sorenson HM, Vines DL, et al. Care of the ventilator circuit and its relation to ventilator-associated pneumonia. Respir Care 2003;48(9):869-879.

69. Lorente L, Lecuona M, Jimenez A, Mora ML, Sierra A. Ventilatorassociated pneumonia using a heated humidifier or a heat and moisture exchanger: a randomized controlled trial [ISRCTN88724583]. Crit Care 2006;10(4):R116.

70. Boots RJ, George N, Faoagali JL, Druery J, Dean K, Heller RF. Double-heater-wire circuits and heat-and-moisture exchangers and the risk of ventilator-associated pneumonia. Crit Care Med 2006; 34(3):687-693.

71. Kallet RH, Quinn TE. The gastrointestinal tract and ventilatorassociated pneumonia. Respir Care 2005;50(7):910-921.

72. Topeli A, Harmanci A, Cetinkaya Y, Akdeniz S, Unal S. Comparison of the effect of closed versus open endotracheal suction systems on the development of ventilator-associated pneumonia. J Hosp Infect 2004;58(1):14-19.

73. Deppe SA, Kelly JW, Thoi LL, Chudy JH, Longfield RN, Ducey JP, et al. Incidence of colonization, nosocomial pneumonia, and mortality in critically ill patients using a Trach Care closed-suction system versus an open-suction system: prospective, randomized study. Crit Care Med 1990;18(12):1389-1393.

74. Akerman E, Larsson C, Ersson A. Clinical experience and incidence of ventilator-associated pneumonia using closed versus open suction-system. Nurs Crit Care 2014;19(1):34-41.

75. Zeitoun SS, de Barros AL, Diccini S. A prospective, randomized study of ventilator-associated pneumonia in patients using a closed vs. open suction system. J Clin Nurs 2003;12(4):484-489.

76. Morrow BM, Mowzer R, Pitcher R, Argent AC. Investigation into the effect of closed-system suctioning on the frequency of pediatric ventilator-associated pneumonia in a developing country. Pediatr Crit Care Med 2012;13(1):e25-e32.

77. Craven DE, Steger KA. Nosocomial pneumonia in mechanically ventilated adult patients: epidemiology and prevention in 1996. Semin Respir Infect 1996;11(1):32-53.

78. Vincent JL. Ventilator-associated pneumonia. J Hosp Infect 2004; 57(4):272-280.

79. Souza LCD, Mota V, Carvalho A, Correa R, Liberio SA, Lopes FF. Association between pathogens from tracheal aspirate and oral biofilm of patients on mechanical ventilation. Braz Oral Res 2017;31: e38.

80. Tuon FF, Gavrilko O, Almeida S, Sumi ER, Alberto T, Rocha JL, et al. Prospective, randomised, controlled study evaluating early modification of oral microbiota following admission to the intensive care unit and oral hygiene with chlorhexidine. J Glob Antimicrob Resist 2017;8:159-163.

81. Scannapieco FA, Bush RB, Paju S. Associations between periodontal disease and risk for nosocomial bacterial pneumonia and chronic obstructive pulmonary disease: a systematic review. Ann Periodontol 2003;8(1):54-69.

82. Shi Z, Xie H, Wang P, Zhang Q, Wu Y, Chen E, et al. Oral hygiene care for critically ill patients to prevent ventilator-associated pneumonia. Cochrane Database Syst Rev 2013(8):CD008367.
83. Hua F, Xie H, Worthington HV, Furness S, Zhang Q, Li C. Oral hygiene care for critically ill patients to prevent ventilator-associated pneumonia. Cochrane Database Syst Rev 2016;10:CD008367.

84. Su KC, Kou YR, Lin FC, Wu CH, Feng JY, Huang SF, et al. A simplified prevention bundle with dual hand hygiene audit reduces early-onset ventilator-associated pneumonia in cardiovascular surgery units: an interrupted time-series analysis. PLoS One 2017; 12(8):e0182252

85. Koff MD, Corwin HL, Beach ML, Surgenor SD, Loftus RW. Reduction in ventilator associated pneumonia in a mixed intensive care unit after initiation of a novel hand hygiene program. J Crit Care 2011;26(5):489-495.

86. Finco G, Musu M, Landoni G, Campagna M, Lai A, Cabrini L, et al. Healthcare-associated respiratory infections in intensive care unit can be reduced by a hand hygiene program: a multicenter study. Aust Crit Care 2018;31(6):340-346.

87. Cook DJ, Reeve BK, Guyatt GH, Heyland DK, Griffith LE, Buckingham L, et al. Stress ulcer prophylaxis in critically ill patients. Resolving discordant meta-analyses. JAMA 1996;275(4):308-314.

88. Alhazzani W, Alshamsi F, Belley-Cote E, Heels-Ansdell D, Brignardello-Petersen R, Alquraini M, et al. Efficacy and safety of stress ulcer prophylaxis in critically ill patients: a network metaanalysis of randomized trials. Intensive Care Med 2018;44(1):1-11.

89. Inglis TJ, Sherratt MJ, Sproat LJ, Gibson JS, Hawkey PM. Gastroduodenal dysfunction and bacterial colonisation of the ventilated lung. Lancet 1993;341(8850):911-913.

90. Guidelines for prevention of nosocomial pneumonia. Centers for Disease Control and Prevention. MMWR Recomm Rep 1997; 46(RR-1):1-79.

91. Pena-Lopez Y, Ramirez-Estrada S, Eshwara VK, Rello J. Limiting ventilator-associated complications in ICU intubated subjects: strategies to prevent ventilator-associated events and improve outcomes. Expert Rev Respir Med 2018;1-14.

92. Magill SS, Fridkin SK. Improving surveillance definitions for ventilator-associated pneumonia in an era of public reporting and performance measurement. Clin Infect Dis 2012;54(3):378-380.

93. Klompas M. Complications of mechanical ventilation-the CDC's new surveillance paradigm. N Engl J Med 2013;368(16):1472-1475.

94. Ding S, Kilickaya O, Senkal S, Gajic O, Hubmayr RD, Li G. Temporal trends of ventilator-associated pneumonia incidence and the effect of implementing health-care bundles in a suburban community. Chest 2013;144(5):1461-1468.

95. Muscedere J, Sinuff T, Heyland DK, Dodek PM, Keenan SP, Wood $\mathrm{G}$, et al. The clinical impact and preventability of ventilator-associated conditions in critically ill patients who are mechanically ventilated. Chest 2013;144(5):1453-1460.

96. Lewis SC, Li L, Murphy MV, Klompas M, Epicenters CDCP. Risk factors for ventilator-associated events: a case-control multivariable analysis. Crit Care Med 2014;42(8):1839-1848.

97. Klompas M, Li L, Kleinman K, Szumita PM, Massaro AF. Associations between ventilator bundle components and outcomes. JAMA Intern Med 2016;176(9):1277-1283.

98. O'Horo JC, Lan H, Thongprayoon C, Schenck L, Ahmed A, Dziadzko M, et al. "Bundle" practices and ventilator-associated events: not enough. Infect Control Hosp Epidemiol 2016;37(12):1453-1457.

99. Harris BD, Thomas GA, Greene MH, Spires SS, Talbot TR. Ventilator bundle compliance and risk of ventilator-associated events. Infect Control Hosp Epidemiol 2018;39(6):637-643.

100. Pileggi C, Mascaro V, Bianco A, Nobile CGA, Pavia M. Ventilator bundle and its effects on mortality among icu patients: a metaanalysis. Crit Care Med 2018;46(7):1167-1174.

101. Mehta S, Burry L, Cook D, Fergusson D, Steinberg M, Granton J, et al. Daily sedation interruption in mechanically ventilated criti- 


\section{Ventilator Bundles in Transition}

cally ill patients cared for with a sedation protocol: a randomized controlled trial. JAMA 2012;308(19):1985-1992.

102. Kollef MH, Chastre J, Fagon JY, Francois B, Niederman MS, Rello $\mathrm{J}$, et al. Global prospective epidemiologic and surveillance study of ventilator-associated pneumonia due to Pseudomonas aeruginosa. Crit Care Med 2014;42(10):2178-2187.

103. Sharpe JP, Magnotti LJ, Weinberg JA, Brocker JA, Schroeppel TJ, Zarzaur BL, et al. Gender disparity in ventilator-associated pneumonia following trauma: identifying risk factors for mortality. J Trauma Acute Care Surg 2014;77(1):161-165.

104. Boyer AF, Schoenberg N, Babcock H, McMullen KM, Micek ST, Kollef MH. A prospective evaluation of ventilator-associated conditions and infection-related ventilator-associated conditions. Chest 2015;147(1):68-81.

105. Rudd KE, Kissoon N, Limmathurotsakul D, Bory S, Mutahunga B, Seymour CW, et al. The global burden of sepsis: barriers and potential solutions. Crit Care 2018;22(1):232.

106. Papakrivou E, Makris D, Manoulakas E, Karvouniaris M, Zakynthinos E. Intra-abdominal hypertension is a risk factor for increased VAP incidence: a prospective cohort study in the ICU of a tertiary hospital. J Intensive Care Med 2018;885066618779369.

107. Goodwin AJ, Nadig NR, McElligott JT, Simpson KN, Ford DW. Where you live matters: the impact of place of residence on severe sepsis incidence and mortality. Chest 2016;150(4):829-836.

108. Barnato AE, Alexander SL, Linde-Zwirble WT, Angus DC. Racial variation in the incidence, care, and outcomes of severe sepsis: analysis of population, patient, and hospital characteristics. Am J Respir Crit Care Med 2008;177(3):279-284.

109. Marik PE, Vasu T, Hirani A, Pachinburavan M. Stress ulcer prophylaxis in the new millennium: a systematic review and metaanalysis. Crit Care Med 2010;38(11):2222-2228.

110. Karatas M, Saylan S, Kostakoglu U, Yilmaz G. An assessment of ventilator-associated pneumonias and risk factors identified in the Intensive Care Unit. Pak J Med Sci 2016;32(4):817-822.

111. Deschepper M, Waegeman W, Eeckloo K, Vogelaers D, Blot S. Effects of chlorhexidine gluconate oral care on hospital mortality: a hospital-wide, observational cohort study. Intensive Care Med 2018;44(7):1017-1026.

112. Price R, MacLennan G, Glen J, Su DC. Selective digestive or oropharyngeal decontamination and topical oropharyngeal chlorhexidine for prevention of death in general intensive care: systematic review and network meta-analysis. BMJ 2014;348: g2197.

113. Hirata K, Kurokawa A. Chlorhexidine gluconate ingestion resulting in fatal respiratory distress syndrome. Vet Hum Toxicol 2002;44(2): 89-91.

114. Ishigami S, Hase S, Nakashima H, Yamada H, Dohgomori H, Natsugoe $\mathrm{S}$, et al. Intravenous chlorhexidine gluconate causing acute respiratory distress syndrome. J Toxicol Clin Toxicol 2001;39(1): 77-80.

115. Xue Y, Zhang S, Yang Y, Lu M, Wang Y, Zhang T, et al. Acute pulmonary toxic effects of chlorhexidine (CHX) following an intratracheal instillation in rats. Hum Exp Toxicol 2011;30(11):17951803.

116. Bouadma L, Klompas M. Oral care with chlorhexidine: beware! Intensive Care Med 2018;44(7):1153-1155.

117. Klompas M, Speck K, Howell MD, Greene LR, Berenholtz SM. Reappraisal of routine oral care with chlorhexidine gluconate for patients receiving mechanical ventilation: systematic review and meta-analysis. JAMA Intern Med 2014;174(5):751-761.

118. National Heart, Lung, and Blood Institute Acute Respiratory Distress Syndrome Clinical Trials Network, Wiedemann HP, Wheeler AP, Bernard GR, Thompson BT, et al. Comparison of two fluidmanagement strategies in acute lung injury. N Engl J Med 2006; 354(24):2564-2575

119. Claure-Del Granado R, Mehta RL. Fluid overload in the ICU: evaluation and management. BMC Nephrol 2016;17(1):109.

120. Malbrain ML, Marik PE, Witters I, Cordemans C, Kirkpatrick AW, Roberts DJ, et al. Fluid overload, de-resuscitation, and outcomes in critically ill or injured patients: a systematic review with suggestions for clinical practice. Anaesthesiol Intensive Ther 2014;46(5): 361-380. 